\title{
An interview with Jonathan Rosa, expert in language, race, and education
}

\author{
Una entrevista amb Jonathan Rosa, expert en llengua, raça $i$ \\ educació
}

\author{
Lídia Gallego-Balsà \\ Universitat Rovira i Virgili
}

\begin{abstract}
Jonathan Rosa is Associate Professor in the Graduate School of Education, Center for Comparative Studies in Race and Ethnicity, and, by courtesy, Departments of Anthropology and Linguistics at Stanford University. His research combines sociocultural and linguistic anthropology to study the co-naturalization of language and race as a key feature of modern governance. Specifically, he analyzes the interplay between racial marginalization, linguistic stigmatization and educational inequity. Dr. Rosa is author of the book, Looking like a Language, Sounding like a Race: Raciolinguistic Ideologies and the Learning of Latinidad (2019, Oxford University Press) and coeditor of the volume Language and Social Justice in Practice (2019, Routledge). In addition to his formal scholarly research, Dr. Rosa is an ongoing participant in public intellectual projects focused on race, education, language, youth, (im)migration, and U.S. Latinxs. His work has appeared in scholarly journals such as Language in Society, American Ethnologist, American Anthropologist, and the Journal of Linguistic Anthropology, as well as media outlets such as MSNBC, NPR, CNN, and Univision.
\end{abstract}

Keywords: Language; Race; Education; Raciolinguistics

\section{Resum}

Jonathan Rosa és professor agregat a la Graduate School of Education, Centre for Comparative Studies in Race and Ethnicity, i, per gentilesa, als departaments d'Antropologia i Lingüística de la Universitat de Stanford. Les seves investigacions combinen l'antropologia sociocultural i la lingüística per estudiar la co-naturalització de la llengua i la raça com a element clau de la governança moderna. Concretament, analitza la interacció entre marginació racial, estigmatització lingüística i desigualtat educativa. El Dr. Rosa és autor del llibre Looking like a Language, Sounding like a Race: Raciolinguistic Ideologies and the Learning of Latinidad (2019, Oxford University Press) i co-editor del volum, Language and Social Justice in Practice (2019, Routledge). A més de la seva investigació formal acadèmica, el Dr. Rosa és un participant permanent en projectes intel-lectuals públics centrats en la raça, l'educació, la llengua, la joventut, la (im)migració i els Latinxs dels Estats Units. El seu treball ha aparegut en revistes acadèmiques com Language in Society, American Ethnologist, American Anthropologist, i Journal of Linguistic Anthropology, a més de mitjans de comunicació com MSNBC, NPR, CNN i Univision.

Paraules clau: Llengua; Raça; Educació; Raciolingüística 


\section{INTERVIEW}

Interviewer: Can you tell us about your academic journey? How did you become an academic?

Rosa: Sure, in the United States we talk about people whose parents haven't gone to college before as first generation college students. I was a first generation college student and I thought that if you go to university then the call is to become a teacher because the only people I knew who had college degrees were teachers. I wanted to be a teacher at the high school level, so I majored in Education, but at the college I attended you weren't allowed to study Education by itself so you had to combine education with a so-called "real major", which is a problematic distinction. I had to figure out what else I would study with education and a friend of mine had taken a linguistics class and seemed to be enjoying it. I was obsessed with grammar and the idea of grammatical correctness, particularly because I was anxious about the ways in which my family used language and the ways I perceived language used in school settings while growing up. I wanted to master all the rules of correctness so that I could sound smart because I was so anxious about my language practices. I studied linguistics because I thought, "Oh, this will help me to really perfect my project of sounding smart." However, the first thing I learned in my linguistics class is there is no such thing as correctness and I thought, "What am I doing here? They've changed the rules!”. I was captivated. I thought that this opportunity to study language structure was so fascinating but I was always interested in issues that went beyond linguistics. I wanted to know about power and identity and in my former linguistics classes those issues would come up but usually at the end of the class - they were sort of to the side. I was really interested in sociolinguistics. That is part one of how I got to be an academic. I received a fellowship when I was an undergraduate for students from underrepresented backgrounds to encourage them to consider pursuing a career in the academy as a professor. They provided funding, so I said, "If you want to pay me, I'll consider anything (laughs)". Based on that fellowship and my interest in sociolinguistics and education I ended up applying to graduate school and discovering the field of linguistic anthropology-where language, power, and identity are not at the end of the conversation, but the whole conversation and that's why I ended up going to the University of Chicago to study sociocultural and linguistic anthropology. That's how I became a professor. I should say it was a very difficult time being in graduate school as a first generation student. It was very alienating. I worked with community organisations and schools through the Puerto Rican Cultural Center in Chicago just as a way of surviving, which actually ended up becoming preliminary 
field research and an important learning opportunity. What I was doing to survive in the university actually allowed me to thrive in the university by working in communities, in the schools and with kids. It's not straightforward to say I got into a $\mathrm{PhD}$ programme and then became a professor, the journey was tumultuous.

Interviewer: Tell us about your current position.

Rosa: I am a faculty member in the Graduate School of Education, the Centre for Comparative Studies and Race and Ethnicity, and, by courtesy, the Departments of Anthropology and Linguistics at Stanford University. For me, being located across all of these different kinds of disciplinary units is the best place to be. I'm everywhere and nowhere and that's the way I would want to be in the world always on some levels. I get to teach theory, which I love to do, and I get to teach practice, which I love to do. Right now I am teaching a course, Racial, Ethnic and Linguistic Formations, which is a really theoretical course, and in a few months I am teaching a course in Equity and Education with pre-service teachers who are going to be high school and elementary school teachers, so I get to teach all the things in the clouds and all of the things on the ground and I think they go very well together. I also teach PhD level courses and undergraduate courses. Right now I am also teaching Introduction to Latinx Studies with a group of undergraduate students where you teach 500 years of colonialism, as well as a couple dozen nations' migration paths to the United States, and the challenge for the students is to reimagine a decolonial world. The paper that I just assigned asks the students to decolonise the world-to decolonise an institution and tell me what it would look like. That's the challenge. I teach the course in the university and at high schools. My students meet one day a week on campus and one day a week with sixty high school sophomores (so 15 and 16 year-olds) who are doing the readings too and we are doing the class together. The idea is that to create an alternative approach to education we have to reimagine everything. Learning does not just happen at the university, learning happens everywhere. The task for the students is to imagine what we call a theory in the flesh, an embodied knowledge that they inherit from their families, communities, and histories of migration, and to see that as a profound site of knowledge production.

Interviewer: How did you develop the term 'raciolinguistics'?

Rosa: Actually with my friend Nelson Flores, we developed the adjective 'raciolinguistic'. That's what I am interested in, in the adjective. Raciolinguistics for me, as a noun, refers to a discipline or a field. I am not as invested in creating a disciplinary field, I am invested in a set of questions, in a perspective. That's why 
a raciolinguistic perspective is what I am really excited about, as a conceptual project rather than a discipline building project. I have been working on this language and race thing for fifteen years. My Master's thesis in 2006 was titled Looking like a language, sounding like a Race, so I have been obsessed with language and race for the longest time and in talking with one of my advisors, Kesha Fikes, she said, "You need to stop saying ethnolinguistic, everyone in linguistics has been talking about ethnolinguistics for a long time but if you are working on race and language, then name it, you need to say what you are doing, tell us what you are up to." My close colleague, Nelson Flores, and I were writing a piece together and we felt like we needed something to name what we were up to and we came up with the idea of 'racialinguistic,' but then we asked, if 'sociolinguistic' comes from social and linguistic, why not use 'raciolinguistic'? It works for us right now as a way of framing what we are calling the co-naturalisation of language and race, which is to consider how do we get these categories, where do they come from, where do these nation-states come from, where do these named languages come from, what historical processes produced all of this, and how do we inherit it, and how do we act like it is just normal, and how by analysing its naturalisation can we imagine an alternative world and then enact that world?

Interviewer: Now that raciolinguistics has gained importance, how do you feel your work has been used?

Rosa: It's interesting. I worry that a lot of people have taken it up as just to mean, "Oh you study race and language, that means that you do raciolinguistics". I am not interested in studying a group of people and their language. That's what I think a lot of people are interested in, studying a language variety and a group of racialized people. They call that raciolinguistics. I am interested in analysing the production of the categories that are involved and unless you are interested in that then we are not talking about the same thing. For example, we call people "Mexican," but what does that even mean? I need people to ask what does it mean rather than presuming it exists in advance of their research. I am under the impression that when I talk about raciolinguistic ideologies a lot of people think that's simply a political project or an ideological project where I'm just trying to be provocative or that I just want to talk about race because it makes people uncomfortable. For me, it is a theoretical problem, the world doesn't make sense to me the way that people have been talking about it. People have been orienting toward categories as though they were just real and as though they were just there and it just doesn't make any sense to me. I think that theoretically, methodologically, analytically this perspective is very important because it is asking us what we are working with, 
what we're perceiving, what we are representing and how we're creating knowledge about people and the world. That is a political project, but it is also a very theoretical project and that is important.

Interviewer: Have you got any comments about raciolinguistic perspectives in relation to other contexts such as Europe or Spain?

Rosa: From some perspectives, race is this American problem and US scholars are trying to export race to the rest of the world, whereas I think, from a lot of our perspectives, race is a global challenge. It's especially important to ask these questions here in Europe because I think if there is any place where these categories have been so naturalised and made so normal so that you can just act as though the world just exists, it's here.

Interviewer: Congratulations on your new book, Looking like a Language, Sounding like a Race: Raciolinguistic Ideologies and the Learning of Latinidad. Tell us a bit about the book and your motivations to write that book.

Rosa: This book was based on my dissertation. The book is an ethnography that looks at a Chicago public high school. Chicago is the third most populous city in the United States. I look at the production of the category of Latino in that context and the ways that self-identified Mexican and Puerto Rican students come to be Latino in this educational setting. That's tied to broader histories of migration, as well as political and economic relations in that context. I'm interested in how what happens in the school is linked to what is happening to the broader community, the neighbourhood, the city of Chicago, the United States, and the world. I ask, how do these people come to be here and how do they come to be imagined as linked to one another through the Spanish language even though they speak mostly English with each other? People imagine Latinidad as a specifically Spanish language phenomenon in the US even though the students use English primarily to orient in relation to one another and in fact the way they recognise their differences are through Spanish. So they imagine Mexican Spanish and Puerto Rican Spanish to be separate languages. There are different lexical items, different grammatical patterns, different forms, so the book is taking up all of these questions about ethnoracial, linguistic, and geopolitical borders-looking at how people construct them and how they push back against them and live beyond them.

Interviewer: Tell us one thing you know to be true in academic life.

Rosa: One thing I know is that our ways of knowing are fundamentally limited in the academy and our ways of producing knowledge are narrow and have 
often been in service of reproducing specific forms of power and specific kinds of worlds. The ways we have created disciplinary boundaries, the ways we've separated the humanities from the sciences, I think that these worlds all go together, I think forms of knowledge are intimately intertwined, but we've created separate disciplines and we've sort of imagined certain people as being skilful in one way and not in another way when in fact we could reimagine all kinds of ways that people are skilful, all kinds of ways that people produce knowledge. So that's the most important thing to me about the academy, to say, "Hey, we need to humble ourselves and recognise all of the ways in which people are creating knowledge and that knowledge is not only created here between these walls". My parents never went to college and they were two of the most brilliant people that I've ever met, who were skilful in so many ways and had to navigate a world that wasn't really made for them. I think that my upbringing allowed me to be successful. If I tell people about my background, they ask, "How did you overcome that?" I don't feel like I overcame that-it was precisely through my parents' experiences and their ways of understanding the world that they equipped me to navigate a whole range of situations in ways that we don't often take into account. For me, it's kind of saying how can the academy humble itself in relation to much bigger ways of knowing, much broader ways of knowing, such that, you know, the academy would be in service of something different rather than simply seeking to organise or accumulate knowledge, something else altogether.

\section{REFERENCE}

Rosa, J. (2019). Looking like a language, sounding like a race: Raciolinguistic ideologies and the learning of Latinidad. Oxford: Oxford University Press.

\section{LÍDIA GALLEGO-BALSÀ}

Is a Serra Húnter Fellow at the Universitat Rovira i Virgili (Tarragona, Spain) and a member of the consolidated research group Cercle de Lingüística Aplicada (2017 SGR 1522). Her research interests include language policy, internationalisation, multilingualism, linguistic ethnography and (critical) discourse analysis.

lidia.gallego@urv.cat

Gallego-Balsà, L. (2020). An interview with Jonathan Rosa, expert in language, race, and education. Bellaterra Journal of Teaching \& Learning Language \& Literature, 13(1), 83-88. https://doi.org/10.5565/rev/jtl3.884 